\title{
Evaluation of some insects as potential feed ingredients for ruminants: chemical composition, in vitro rumen fermentation and methane emissions
}

\author{
A. Jayanegara*, N. Yantina, B. Novandri, E. B. Laconi, Nahrowi and M. Ridla \\ Faculty of Animal Science, Bogor Agricultural University, \\ Jl. Agatis, Darmaga Campus, Bogor 16680 - Indonesia \\ *Corresponding E-mail: anuraga.jayanegara@gmail.com \\ Received February 24, 2017; Accepted June 12, 2017
}

\begin{abstract}
ABSTRAK
Penelitian ini bertujuan untuk mengevaluasi kandungan nutrien, fermentasi rumen, kecernaan dan emisi metana secara in vitro sejumlah serangga yakni jangkrik (JFC), ulat hongkong (MW) dan larva black soldier fly berumur 1 dan 2 minggu (BSF1 dan BSF2). Sampel serangga dikeringkan pada suhu $60^{\circ} \mathrm{C}$ selama 24 jam, kemudian digiling berukuran $1 \mathrm{~mm}$. Sampel yang telah digiling kemudian dianalisis kandungan nutriennya serta diuji secara in vitro. Inkubasi in vitro dilakukan pada water bath pada suhu $39^{\circ} \mathrm{C}$ selama $48 \mathrm{~h}$, serta dilakukan dalam tiga ulangan di mana masing-masing ulangan direpresentasikan dengan dua botol inkubasi. Hasil menunjukkan bahwa semua serangga yang diujikan mengandung protein kasar yang tinggi yakni di atas $40 \% \mathrm{BK}$. Proporsi neutral detergent insoluble $C P$ (NDICP) dan neutral detergent insoluble $C P$ (ADICP) pada serangga lebih tinggi dibandingkan dengan bungkil kedelai, terutama sangat tinggi pada BSF2. Konsentrasi $\mathrm{NH}_{3}$ tertinggi terdapat pada inkubasi JFC dibandingkan dengan yang lain $(\mathrm{P}<0,05)$ dan paling rendah pada BSF2. Semua sampel serangga memiliki KCBK dan KCBO yang lebih rendah dibandingkan dengan bungkil kedelai $(\mathrm{P}<0,05)$. Emisi metana dari serangga pada jam inkubasi ke-12, 24 dan 48 jam lebih rendah dibandingkan dengan bungkil kedelai $(\mathrm{P}<0,05)$. Disimpulkan bahwa serangga tinggi akan protein dan menghasilkan emisi metana yang rendah, namun kecernaannya relatif rendah sehingga dapat membatasi penggunaannya.
\end{abstract}

Kata Kunci: serangga, jangkrik, ulat hongkong, black soldier fly, fermentasi rumen

\begin{abstract}
This experiment was aimed to evaluate chemical composition, in vitro rumen fermentation, digestibility and methane emissions of some insects, i.e. Jamaican field cricket (JFC), mealworm (MW) and black soldier fly larvae age 1 and 2 weeks (BSF1 and BSF2). Insect samples were oven-dried at $60^{\circ} \mathrm{C}$ for $24 \mathrm{~h}$, and ground to pass a $1 \mathrm{~mm}$ sieve. The ground samples were used subsequently for chemical composition determination and in vitro rumen fermentation test. Incubation was carried out in a water bath maintained at $39{ }^{\circ} \mathrm{C}$ for $48 \mathrm{~h}$ in three replicates. Results revealed that all insect meals contained high crude protein, i.e. above $40 \%$ DM. Proportions of neutral detergent insoluble $C P$ (NDICP) and neutral detergent insoluble $C P$ (ADICP) were high in the insect meals than that of soybean meal (SBM), and these were particularly very high in BSF2. All insect meals had lower IVDMD and IVOMD than that of SBM $(\mathrm{P}<0.05)$. All insect meals had lower methane emissions as compared to SBM at 12,24 and $48 \mathrm{~h}(\mathrm{P}<0.05)$. It can be concluded that insect meals are potential protein supplements and have low methane emissions in vitro. However, their digestibility is rather low and may limit their utilization.
\end{abstract}

Keywords :insect, cricket, mealworm, black soldier fly, rumen fermentation 


\section{INTRODUCTION}

Provision of adequate feed supply for livestock faces future challenge due to a decrease of land for cultivation of feed resources. On the other hand, the rapidly growing human population increases the requirement of food including food from animal origin such as meat, milk and egg; such condition may further elevate the demand of feed for feeding the livestock. Climate change may worsen feed provision by declining feed production in many areas in the world (Smith and Gregory, 2013), taking into consideration that current adaptation and mitigation measures are generally unable to sufficiently overcome the problem. Therefore search for alternative feed resources is of importance as a strategy to meet feed demand in the future.

In recent years, insects have been considered as promising alternative feed resources especially as protein sources. With regard to feed production, insects have a number of advantages in comparison to feed resources from plant and animal origins such as low greenhouse gas and ammonia emissions, low feed conversion ratio, low risk of zoonotic infection, low water use, and able to efficiently convert (and reduce) organic waste disposal into their body mass within a short period of time (Van Huis, 2013). Further, with regard to their nutritional values, most of insects contain high crude protein contents with relatively good amino acid profiles (Sanchez-Muros et al., 2014), making them quite promising to be used as ingredients for feeding of various livestock species. It has to be noted that nutritional values of insects may vary greatly depend on species or phases of development. Insects have been tested as feed ingredients in the diets of poultry, swine and fish (Sanchez-Muros et al., 2014; Jozefiak et al., 2016). However, data on the use of insects as feeds of ruminants are presently still limited.

The objective of this experiment was to evaluate some insects, i.e. Jamaican field cricket (Gryllus assimilis), mealworm (Tenebrio molitor) and black soldier fly larvae (Hermetia illucens) regarding their potential use as feed ingredients for ruminants; the insects were evaluated for their chemical composition, in vitro rumen fermentation, digestibility and methane emissions.

\section{MATERIALS AND METHODS}

\section{Sample Collection and Preparation}

Insects used in this study included Jamaican field cricket (JFC, Gryllus assimilis), mealworm (MW, Tenebrio molitor) and black soldier fly larvae (BSF, Hermetia illucens); they were obtained from commercial growers. The ages of JFC, MW and BSF were 7, 4, and 1 (BSF1) and 2 (BSF2) weeks, respectively. Shortly after collection, insects materials were stored in a freezer $\left(-20^{\circ} \mathrm{C}\right)$ overnight and then oven-dried at $60^{\circ} \mathrm{C}$ for $24 \mathrm{~h}$. Dried samples were ground to pass a $1 \mathrm{~mm}$ sieve by using a hammer mill. These ground samples were used subsequently for chemical composition determination and in vitro rumen fermentation test. Additionally, soybean meal (SBM) was included in the evaluation as a reference of conventional protein supplement in ruminant diets.

\section{Chemical composition determination}

Samples were subjected to proximate analysis, i.e. determinations of dry matter (DM), ash, organic matter $(\mathrm{OM})$, crude protein $(\mathrm{CP})$, ether extract (EE) and crude fiber (CF) by following AOAC procedures (AOAC, 2005). Briefly, DM content was determined by putting samples in an oven set at $105^{\circ} \mathrm{C}$ for $24 \mathrm{~h}$. Ash was obtained by burning samples in a furnace at $500^{\circ} \mathrm{C}$ for $3 \mathrm{~h}$. The difference between DM and ash was considered as OM. Determination of CP was according to Kjeldahl method by employing destruction, distillation and titration procedures. Analysis of CF was performed through sequential boiling of samples in acid and alkali solutions each for $30 \mathrm{~min}$, whereas $\mathrm{EE}$ was obtained by using soxhlet extractor and petroleum ether to extract the fat content. Neutral detergent fiber (NDF) and acid detergent fiber (ADF) were determined according to Van Soest et al. (1991); these were performed by boiling samples in neutral detergent and acid detergent solutions, respectively, for $1 \mathrm{~h}$. Analysis of NDF was conducted without $\alpha$-amylase and sodium sulfite, and the value was expressed exclusive of residual ash. Residues obtained in NDF and ADF analyses were continued with $\mathrm{CP}$ determination to obtain neutral detergent insoluble CP (NDICP) and acid detergent insoluble CP (ADICP) contents as described by Licitra et al. (1996). All the chemical composition analyses were performed in duplicate.

\section{In vitro Rumen Fermentation}

Samples were incubated in vitro with buffered rumen fluid mixture by following the 
procedure from Theodorou et al. (1994). Rumen fluid was collected before morning feeding from a rumen fistulated Friesian Holstein cow located at Indonesian Research Center for Animal Production, Bogor. Before use, rumen fluid was filtered through four layers of gauze. An amount of $0.75 \mathrm{~g}$ sample was inserted into a $125 \mathrm{ml}$ serum bottle and added with $75 \mathrm{ml}$ buffered rumen fluid (ratio rumen fluid:buffer was 1:4 v/v). Serum bottles were the sealed with butyl rubber stoppers and aluminum crimp seals to start the incubation. Incubation was performed in a water bath maintained at $39^{\circ} \mathrm{C}$ for $48 \mathrm{~h}$. Gas production was vented and recorded at 2, 4, 6, 8, 12, 24, 36 and $48 \mathrm{~h}$ after incubation using a syiringe. Manual shaking was conducted at each time of gas production recording. Methane measurement was also performed at each time of gas production recording by following the method described in Fievez et al. (2005). After $48 \mathrm{~h}$ incubation, serum bottles were centrifuged to separate supernatant and residue. Supernatant obtained after $48 \mathrm{~h}$ incubation was analyzed for $\mathrm{pH}$ by using a $\mathrm{pH}$ meter, and total volatile fatty acid (VFA) and ammonia concentrations were determined as described in Jayanegara et al. (2016). Residue was further incubated with $75 \mathrm{ml}$ pepsin- $\mathrm{HCl} 0.2$ $\mathrm{N}$ solution for another $48 \mathrm{~h}$ (Tilley and Terry, 1963). In vitro dry matter digestibility (IVDMD) and in vitro organic matter digestibility (IVOMD) were obtained by subtracting DM and $\mathrm{OM}$ residues from their initial $\mathrm{DM}$ and $\mathrm{OM}$ amounts prior to incubation, respectively. The in vitro incubation was performed in three runs and each run was represented by two serum bottles. Allocation of treatments into experimental units followed a randomized complete block design in which different in vitro runs served as the blocks (replicates). Two bottles per run without any substrate but containing buffered rumen fluid were also incubated to serve as blanks.

\section{Data analysis}

Data were analyzed by analysis of variance with the following statistical model:

$\mathrm{Y}_{\mathrm{ij}}=\mu+\alpha_{\mathrm{i}}+\beta_{\mathrm{j}}+\varepsilon_{\mathrm{ij}}$

where $Y_{i j}$ is the observed value, $\mu$ is the overall mean, $\alpha_{i}$ is the treatment effect, $\beta_{j}$ is the block effect (replicate) and $\varepsilon_{\mathrm{ij}}$ is the random residual error. Data on gas production kinetics were fitted against a modified equation of Ørskov and McDonald (1979) as follow:

$$
\mathrm{GP}=\mathrm{b}\left(1-\mathrm{e}^{-\mathrm{ct}}\right)
$$

where GP is gas production $(\mathrm{ml} / \mathrm{g} \mathrm{DM}), \mathrm{b}$ is gas production potential $(\mathrm{ml} / \mathrm{g} \mathrm{DM}), \quad \mathrm{c}$ is gas production rate $(/ \mathrm{h})$ and $\mathrm{t}$ is incubation period $(\mathrm{h})$. When a parameter showed significantly different at $\mathrm{P}<0.05$, the analysis was continued with a posthoc test namely Duncan's multiple range test. The statistical analysis was performed by using SAS software version 9.1.

\section{RESULTS}

All insect meals contained high $\mathrm{CP}$, i.e. above $40 \%$ DM (Table 1). The CP contents of JFC and MW were above $60 \%$ DM whereas BSF 1 and BSF2 contained lower CP. Generally the insect meals had EE higher than 20\% DM except for JFC. Insect meals were marked with their high fiber in comparison to SBM as shown by CF, NDF and ADF parameters. Among the insect meals, BSF contained considerably higher NDF than those of the others, and BSF2 had higher CF, NDF and ADF as compared to BSF1. Proportions of NDICP and ADICP to CP were also high in the insect meals than that of SBM, and these were particularly very high in BSF2.

With regard to in vitro rumen fermentation characteristics and digestibility, incubation of insect meals and SBM revealed similar total VFA concentration but different $\mathrm{NH}_{3}$ concentration (Table 2). Concentration of $\mathrm{NH}_{3}$ was the highest in JFC incubation as compared to other feedstuffs $(\mathrm{P}<0.05)$ and the lowest in BSF2. Digestibility of SBM, both IVDMD and IVOMD, was the highest for SBM. All insect meals had lower IVDMD and IVOMD than that of SBM $(\mathrm{P}<0.05)$. Among the insect meals, the highest IVDMD and IVOMD was observed in JFC and the lowest was in BSF2.

Total gas production in the incubation of SBM was the highest at various time point intervals (Figure 1). Among the insects, MW produced the highest total gas production whereas BSF2 was the lowest at $48 \mathrm{~h}$ after incubation (Table 3). Gas production potential of BSF1 was higher than that of BSF2 $(\mathrm{P}<0.05)$. Both BSF1 and BSF2 were fermented more rapidly in comparison to JFC, MW and SBM as shown by the higher gas production rate $(\mathrm{P}<0.05)$. All insect meals had lower methane emissions as compared to SBM at 12,24 and $48 \mathrm{~h}(\mathrm{P}<0.05$; Table 4$)$. Among the insects, the order of methane emissions per unit of digestible OM (from lowest to highest) was JFC $<\mathrm{BSF} 2<\mathrm{BSF} 1<\mathrm{MW}$. 
Table 1. Chemical Composition (\% Dry Matter) of Jamaican Field Cricket (JFC), Mealworm (MW), Black Soldier Fly Larvae Age 1 Week (BSF1), Black Soldier Fly Larvae Age 2 Weeks (BSF2) and Soybean Meal (SBM)

\begin{tabular}{lrrrrr}
\hline \multicolumn{1}{c}{ Component } & JFC & MW & BSF1 & BSF2 & SBM \\
\hline DM & 95.9 & 96.4 & 89.5 & 91.5 & 87.9 \\
OM & 97.8 & 97.7 & 94.1 & 91.9 & 91.6 \\
Ash & 2.2 & 2.3 & 5.9 & 8.1 & 8.4 \\
CP & 67.7 & 64.5 & 44.7 & 44.9 & 50.0 \\
EE & 14.5 & 20.3 & 34.8 & 29.1 & 2.7 \\
CF & 14.6 & 12.2 & 11.0 & 16.4 & 7.9 \\
NFE & 1.0 & 0.7 & 3.6 & 1.5 & 31.0 \\
NDF & 39.3 & 41.4 & 76.9 & 81.1 & 18.8 \\
ADF & 10.8 & 10.8 & 10.7 & 11.6 & 8.3 \\
NDICP $(\% C P)$ & 37.9 & 26.4 & 47.0 & 65.0 & 16.6 \\
ADICP $(\% C P)$ & 9.8 & 6.7 & 9.2 & 19.8 & 4.7 \\
\hline
\end{tabular}

ADF, acid detergent fiber; ADICP, acid detergent insoluble crude protein; CF, crude fiber; $\mathrm{CP}$, crude protein; DM, dry matter; EE, ether extract; NDF, neutral detergent fiber; NDICP, neutral detergent insoluble crude protein; NFE, nitrogen free extract; OM, organic matter.

Table 2. In vitro Rumen Fermentation Characteristics and Digestibility of Some Insects after 48 h Incubation Period

\begin{tabular}{lccccc}
\multicolumn{1}{c}{ Feedstuff } & $\mathrm{pH}$ & $\begin{array}{c}\text { VFA } \\
(\mathrm{mmol} / \mathrm{l})\end{array}$ & $\begin{array}{c}\mathrm{NH}_{3} \\
(\mathrm{mmol} / \mathrm{l})\end{array}$ & $\begin{array}{c}\text { IVDMD } \\
(\%)\end{array}$ & $\begin{array}{c}\text { IVOMD } \\
(\%)\end{array}$ \\
\hline JFC & $7.37^{\mathrm{b}}$ & 134 & $60.2^{\mathrm{c}}$ & $64.2^{\mathrm{b}}$ & $64.7^{\mathrm{b}}$ \\
MW & $7.25^{\mathrm{b}}$ & 128 & $42.5^{\mathrm{b}}$ & $59.6^{\mathrm{ab}}$ & $59.7^{\mathrm{ab}}$ \\
$\mathrm{BSF} 1$ & $7.25^{\mathrm{b}}$ & 113 & $26.6^{\mathrm{a}}$ & $55.5^{\mathrm{a}}$ & $54.4^{\mathrm{ab}}$ \\
BSF2 & $7.28^{\mathrm{b}}$ & 103 & $23.4^{\mathrm{a}}$ & $53.8^{\mathrm{a}}$ & $51.8^{\mathrm{a}}$ \\
SBM & $7.10^{\mathrm{a}}$ & 135 & $43.4^{\mathrm{b}}$ & $88.8^{\mathrm{c}}$ & $85.8^{\mathrm{c}}$ \\
& & & & & \\
SEM & 0.031 & 5.16 & 3.69 & 3.61 & 3.56 \\
P-value & 0.010 & 0.166 & $<0.001$ & $<0.001$ & $<0.001$ \\
\hline
\end{tabular}

Different superscripts within the same column indicate significantly different at $\mathrm{P}<0.05$.

BSF1, black soldier fly larvae age 1 week; BSF2, black soldier fly larvae age 2 weeks; IVDMD, in vitro dry matter digestibility; IVOMD, in vitro organic matter digestibility; JFC, Jamaican field cricket; MW, mealworm; $\mathrm{NH}_{3}$, ammonia; SBM, soybean meal; SEM, standard error of mean; VFA, volatile fatty acid.

\section{DISCUSSION}

Insects are among potential protein sources for feeding of livestock. High CP contents found in $\mathrm{JFC}, \mathrm{MW}$ and BSF confirmed some previous studies (Bovera et al., 2015; Cullere et al., 2016; Taufek et al., 2016). Insects also contain substantial amounts of EE, particularly in the 


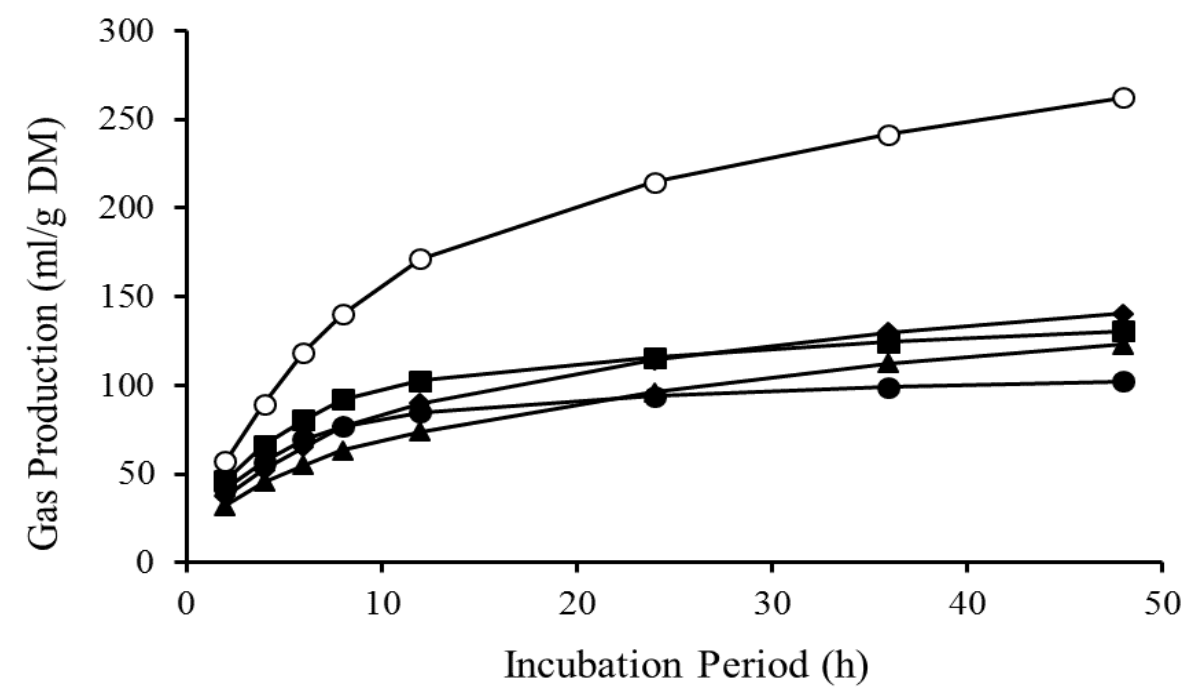

Figure 1. Gas production of Jamaican field cricket (- $\mathbf{\Delta}-)$, mealworm (- $\downarrow-)$, black soldier fly larvae age 1 week (-m-), black soldier fly larvae age 2 weeks (-๑-) and soybean meal (-o-) at different incubation period.

Table 3. In vitro Gas Production and Kinetic Parameters of Some Insects

\begin{tabular}{lccccc}
\multicolumn{1}{c}{ Feedstuff } & $\begin{array}{c}\mathrm{Gas}_{12} \\
(\mathrm{ml} / \mathrm{g} \mathrm{DM})\end{array}$ & $\begin{array}{c}\mathrm{Gas}_{24} \\
(\mathrm{ml} / \mathrm{g} \mathrm{DM})\end{array}$ & $\begin{array}{c}\mathrm{Gas}_{48} \\
(\mathrm{ml} / \mathrm{g} \mathrm{DM})\end{array}$ & $\begin{array}{c}\mathrm{b} \\
(\mathrm{ml} / \mathrm{g} \mathrm{DM})\end{array}$ & $\begin{array}{c}\mathrm{c} \\
(/ \mathrm{h})\end{array}$ \\
\hline JFC & $73.8^{\mathrm{a}}$ & $96.0^{\mathrm{a}}$ & $123.0^{\mathrm{b}}$ & $115.2^{\mathrm{b}}$ & $0.104^{\mathrm{a}}$ \\
MW & $89.8^{\mathrm{b}}$ & $114.3^{\mathrm{b}}$ & $140.3^{\mathrm{d}}$ & $132.8^{\mathrm{d}}$ & $0.113^{\mathrm{a}}$ \\
BSF1 & $102.5^{\mathrm{c}}$ & $115.8^{\mathrm{b}}$ & $130.5^{\mathrm{c}}$ & $122.8^{\mathrm{c}}$ & $0.189^{\mathrm{b}}$ \\
BSF2 & $84.7^{\mathrm{b}}$ & $93.8^{\mathrm{a}}$ & $102.2^{\mathrm{a}}$ & $97.0^{\mathrm{a}}$ & $0.257^{\mathrm{c}}$ \\
SBM & $171.2^{\mathrm{d}}$ & $214.5^{\mathrm{c}}$ & $262.3^{\mathrm{e}}$ & $251.0^{\mathrm{e}}$ & $0.103^{\mathrm{a}}$ \\
& & & & & \\
SEM & 6.69 & 8.58 & 10.9 & 10.5 & 0.016 \\
P-value & $<0.001$ & $<0.001$ & $<0.001$ & $<0.001$ & $<0.001$ \\
\hline
\end{tabular}

Different superscripts within the same column are significantly different at $\mathrm{P}<0.05$.

$\mathrm{Gas}_{12}$, gas production after $12 \mathrm{~h}$ incubation; Gas 24 , gas production after $24 \mathrm{~h}$ incubation; Gas 48 , gas production after $48 \mathrm{~h}$ incubation; $\mathrm{b}$, gas production potential; $\mathrm{c}$, gas production rate.

BSF1, black soldier fly larvae age 1 week; BSF2, black soldier fly larvae age 2 weeks; DM, dry matter; JFC, Jamaican field cricket; MW, mealworm; SBM, soybean meal; SEM, standard error of mean.

form of polyunsaturated fatty acids (PUFA) (Sanchez-Muros et al., 2014). House cricket, mealworm and black soldier fly have been reported to be rich in linoleic acid; more than $35 \%$ of total fatty acids present in these insects were in the form of linoleic acid (Oonincx et al., 2015). Many insects also contain substantial amount of monounsaturated fatty acids (MUFA) especially oleic acid (Sanchez-Muros et al., 2014).

Apart from high in CP and EE, insects are high in fiber contents as shown by CF, NDF and ADF parameters. Apparently exoskeleton of insects contribute to such high fiber contents. Chitin, a long-chain polymer of an Nacetylglucosamine, is a main component present in the exoskeleton of insects (Chaudhari et al., 
Table 4. .In vitro Methane (CH4) Emissions of Some Insects

\begin{tabular}{lcccc}
\hline Feedstuff & $\begin{array}{c}\mathrm{CH}_{4,12} \\
(\mathrm{ml} / \mathrm{g} \mathrm{DM})\end{array}$ & $\mathrm{CH}_{4.24}(\mathrm{ml} / \mathrm{g} \mathrm{DM})$ & $\begin{array}{c}\mathrm{CH}_{4} 48 \\
(\mathrm{ml} / \mathrm{g} \mathrm{DM})\end{array}$ & $\begin{array}{c}\mathrm{CH}_{4} / \mathrm{DOM} \\
(\mathrm{ml} / \mathrm{g})\end{array}$ \\
\hline JFC & $14.3^{\mathrm{a}}$ & $23.6^{\mathrm{a}}$ & $30.6^{\mathrm{a}}$ & $48.3^{\mathrm{a}}$ \\
MW & $23.5^{\mathrm{b}}$ & $34.6^{\mathrm{b}}$ & $38.0^{\mathrm{b}}$ & $65.2^{\mathrm{b}}$ \\
BSF1 & $27.6^{\mathrm{b}}$ & $30.5^{\mathrm{b}}$ & $31.3^{\mathrm{ab}}$ & $61.1^{\mathrm{ab}}$ \\
BSF2 & $23.1^{\mathrm{b}}$ & $25.0^{\mathrm{a}}$ & $25.0^{\mathrm{a}}$ & $52.4^{\mathrm{ab}}$ \\
SBM & $58.0^{\mathrm{c}}$ & $77.0^{\mathrm{c}}$ & $94.4^{\mathrm{c}}$ & $120.1^{\mathrm{c}}$ \\
& & & & \\
SEM & 3.78 & 4.89 & 6.23 & 7.01 \\
P-value & $<0.001$ & $<0.001$ & $<0.001$ & $<0.001$ \\
\hline
\end{tabular}

Different superscripts within the same column are significantly different at $\mathrm{P}<0.05$.

$\mathrm{CH}_{4.12}$, methane measured after $12 \mathrm{~h}$ incubation; $\mathrm{CH} 4.24$, methane measured after $24 \mathrm{~h}$ incubation; $\mathrm{CH}_{4.48}$, methane measured after $48 \mathrm{~h}$ incubation; $\mathrm{CH}_{4} / \mathrm{DOM}$, methane per unit of digested organic matter.

BSF1, black soldier fly larvae age 1 week; BSF2, black soldier fly larvae age 2 weeks; DM, dry matter; JFC, Jamaican field cricket; MW, mealworm; SBM, soybean meal; SEM, standard error of mean.

2011) and this component is regarded as fiber (Finke, 2007). It is apparent that chitin is insoluble in neutral detergent solution but soluble, at least partially, in acid detergent solution although this requires a confirmatory study. Further, since chitin contains nitrogenous group in the molecule it also contributes to the high proportions of NDICP and ADICP. Exoskeleton develops with the increase of age (Zhu et al., 2016) and therefore chitin proportion per unit of DM increases as well. It was shown by the higher CF, NDF, ADF, NDICP and ADICP of BSF2 as compared to those of BSF1. Such high fiber contents in insect meals resulted in lower IVDMD and IVOMD as compared to SBM. Further, insect meals produced low total gas production due to high fiber and EE contents than those of SBM. Gas in the in vitro system is formed mainly from carbohydrate fermentation and contribution of EE to gas production is negligible (Getachew et al., 1998).

High $\mathrm{NH}_{3}$ concentration in the incubation of JFC is apparently related to its high CP content. Protein undegoes proteolysis and deamination by proteolytic microbes in the rumen to form $\mathrm{NH}_{3}$ (Owens et al., 2014). Formation of $\mathrm{NH}_{3}$ in the rumen does not solely depend on $\mathrm{CP}$ concentration but also other factors such as $\mathrm{CP}$ fraction (Jayanegara et al., 2016), protein degradation rate, rate of passage, utilization of
$\mathrm{NH}_{3}$ to form microbial protein and ruminal absorption of $\mathrm{NH}_{3}$ through rumen wall to the blood stream (Bach et al., 2005). Relatively low $\mathrm{NH}_{3}$ concentration observed in BSF2 incubation is related to its high ADICP content; ADICP or protein fraction $\mathrm{C}$ is considered to be undegraded in the rumen (Licitra et al., 1996). Concentrations of $\mathrm{NH}_{3}$ for all feeds in the present study were relatively high in comparison to other studies. Apart from the generally high CP contents of all feeds tested, apparently measurement performed at $48 \mathrm{~h}$ after incubation leads to an accumulation of $\mathrm{NH}_{3}$ concentration. This is certainly different figure when the sampling time for $\mathrm{NH}_{3}$ measurement is conducted at shorter period after in vitro incubation as done in other studies (Cone and Van Gelder, 1999; Jayanegara et al., 2013). Such high $\mathrm{NH}_{3}$ concentration was confirmed by the increase of $\mathrm{pH}$ to 7.1 or higher after incubation from an initial $\mathrm{pH}$ of 6.9.

Methane emissions of all insect meals were much lower as compared to SBM. Lower digestibility of insect meals causes lower $\mathrm{H}_{2}$ production which is a main substrate for methanogenesis (Jayanegara et al., 2015). However, it is not the only reason for the low methane since there was also a genuine decrease of $\mathrm{CH}_{4} / \mathrm{DOM}$ of insect meals than that of SBM. Further, high EE contents contribute to low methane emissions since some fatty acids 
especially medium chain fatty acids (MCFA) are toxic to methanogens (Machmuller, 2006). Further, polyunsaturated fatty acids (PUFA) present in insect meals are able to act as hydrogen sinks (Martin et al., 2010). Aparently chitin may also play a role in decreasing methane emissions presumably by reducing $\mathrm{H}_{2}$ supply for methanogenesis. Effects of chitin on rumen methanogenesis and abundance of methanogens to date are limitedly investigated. However, there were some experiments reported that chitosan (a natural biopolymer derived through chitin deacetylation) decreased ruminal methane emissions and/or methanogen populations (Goiri et al., 2009; 2010; Belanche et al., 2016).

\section{CONCLUSION}

Insect meals, i.e. Jamaican field cricket (JFC), mealworm (MW) and black soldier fly (BSF) are potential feed ingredients for ruminants especially as protein supplements. They are rich in EE as well and therefore may supply some essential fatty acid requirements of the animals. All the insect meals have low methane emissions in vitro. However, their digestibility is rather low and may limit their utilization. Certain treatments or processing methods to remove the exoskeleton fraction or chitin may be required to elevate the feeding values of insect meals; these warrant further studies together with their feeding trials in vivo.

\section{ACKNOWLEDGEMENT}

This research was funded by Indonesian Ministry of Research, Technology and Higher Education through "Penelitian Unggulan Perguruan Tinggi" research grant, year 2016, contract number 079/SP2H/LT/DRPM/II/2016.

\section{REFERENCES}

AOAC (Association of Official Analytical Chemists). 2005. Official Methods of Analysis. 18th ed. AOAC International, Arlington, VA, USA.

Bach, A., S. Calsamiglia and M.D. Stern. 2005. Nitrogen metabolism in the rumen. J. Dairy Sci. 88:E9-E21.

Belanche, A., E. Pinloche, D. Preskett and C.J. Newbold. 2016. Effects and mode of action of chitosan and ivy fruit saponins on the microbiome, fermentation and methanogenesis in the rumen simulation technique. FEMS Microbiol. Ecol. 92:fiv160.

Bovera, F., G. Piccolo, L. Gasco, S. Marono, R. Laponte, G. Vassalotti, V. Mastellone, P. Lombardi, Y.A. Attia and A. Nizza. 2015. Yellow mealworm larvae (Tenebrio molitor L.) as a possible alternative to soybean meal in broiler diets. Br. Poult. Sci. 56:569-575.

Chaudhari, S.S., Y. Arakane, C.A. Specht, B. Moussian, D.L. Boyle, Y. Park, K.J. Kramer, R.W. Beeman and S. Muthukrishnan. 2011. Knickkopf protein protects and organizes chitin in the newly synthesized insect exoskeleton. Proc. Natl. Acad. Sci. 108:17028-17033.

Cone, J.W., and A.H. Van Gelder. 1999. Influence of protein fermentation on gas production profiles. Anim. Feed Sci. Technol. 76:251264.

Cullere, M., G. Tasoniero, V. Giaccone, R. MiottiScapin, E. Claeys, S. De Smet and A. Dalle Zotte. 2016. Black soldier fly as dietary protein source for broiler quails: apparent digestibility, excreta microbial load, feed choice, performance, carcass and meat traits. Animal 10:1923-1930.

Fievez, V., O.J. Babayemi and D. Demeyer. 2005. Estimation of direct and indirect gas production in syringes: A tool to estimate short chain fatty acid production that requires minimal laboratory facilities. Anim. Feed Sci. Technol. 123-124:197-210.

Finke, M.D. 2007. Estimate of chitin in raw whole insects. Zoo Biol. 26:105-115.

Getachew, G., M. Blummel, H.P.S. Makkar and $\mathrm{K}$. Becker. 1998. In vitro gas measuring techniques for assessment of nutritional quality of feeds: a review. Anim. Feed Sci. Technol. 72:261-281.

Goiri, I., A. Garcia-Rodriguez and L.M. Oregui. 2009. Effect of chitosans on in vitro rumen digestion and fermentation of maize silage. Anim. Feed Sci. Technol. 148:276-287.

Goiri, I., L.M. Oregui and A. Garcia-Rodriguez. 2010. Use of chitosans to modulate ruminal fermentation of a 50:50 forage-toconcentrate diet in sheep. J. Anim. Sci. 88:749-755.

Jayanegara, A., S. Marquardt, E. Wina, M. Kreuzer and F. Leiber. 2013. In vitro indications for favourable non-additive effects on ruminal methane mitigation 
between high-phenolic and high-quality forages. Br. J. Nutr. 109:615-622.

Jayanegara, A., G. Goel, H.P.S. Makkar and K. Becker. 2015. Divergence between purified hydrolysable and condensed tannin effects on methane emission, rumen fermentation and microbial population in vitro. Anim. Feed Sci. Technol. 209:60-68.

Jayanegara, A., S.P. Dewi and M. Ridla. 2016. Nutrient content, protein fractionation, and utilization of some beans as potential alternatives to soybean for ruminant feeding. Med. Pet. 39:195-202.

Jozefiak, D., A. Jozefiak, B. Kieronczyk, M. Rawski, S. Swiatkiewicz, J. Dlugosz and R.M. Engberg. 2016. Insects - a natural nutrient source for poultry - a review. Ann. Anim. Sci. 16:297-313.

Licitra, G., T.M. Hernandez and P.J. Van Soest. 1996. Standardization of procedures for nitrogen fractionation of ruminant feeds. Anim. Feed Sci. Technol. 57:347-358.

Machmuller, A. 2006. Medium-chain fatty acids and their potential to reduce methanogenesis in domestic ruminants. Agric. Ecosyst. Environ. 112:107-114.

Martin, C., D.P. Morgavi and M. Doreau. 2010. Methane mitigation in ruminants: from microbe to the farm scale. Animal 4:351365.

Oonincx, D.G.A.B., S. Van Broekhoven, A. Van Huis and J.J.A. Van Loon. 2015. Feed conversion, survival and development, and composition of four insect species on diets composed of food by-products. Plos One 10:e0144601.

Ørskov, E.R., and I. Mcdonald. 1979. The estimation of protein degradability in the rumen from incubation measurements weighted according to rate of passage. J.
Agric. Sci. 92:499-503.

Owens, F.N., S. Qi and D.A. Sapienza. 2014. Applied protein nutrition of ruminants current status and future directions. Prof. Anim. Sci. 30:150-179.

Sanchez-Muros, M.J., F.G. Barroso and F. Manzano-Agugliaro. 2014. Insect meal as renewable source of food for animal feeding: a review. J. Clean. Prod. 65:16-27.

Smith, P., and P.J. Gregory. 2013. Climate change and sustainable food production. Proc. Nutr. Soc. 72:21-28.

Taufek, N.M., F. Aspani, H. Muin, A.A. Raji, S.A. Razak and Z. Alias. 2016. The effect of dietary cricket meal (Gryllus bimaculatus) on growth performance, antioxidant enzyme activities, and haematological response of African catfish (Clarias gariepinus). Fish Physiol. Biochem. 42:1143-1155.

Theodorou, M.K., B.A. Williams, M.S. Dhanoa, A.B. McAllan and J. France. 1994. A simple gas production method using a pressure transducer to determine the fermentation kinetics of ruminant feeds. Anim. Feed Sci. Technol. 48:185-197.

Tilley, J.M.A., and R.A. Terry. 1963. A two-stage technique for the in vitro digestion of forage crops. Grass For. Sci. 18:104-111.

Van Huis, A. 2013. Potential of insects as food and feed in assuring food security. Ann. Rev. Entomol. 58:563-583.

Van Soest, P.J., J.B. Robertson and B.A. Lewis. 1991. Methods for dietary fiber, neutral detergent fiber, and nonstarch polysaccharides in relation to animal nutrition. J. Dairy Sci. 74:3583-3597.

Zhu, K.Y., H. Merzendorfer, W. Zhang, J. Zhang and S. Muthukrishnan. 2016. Biosynthesis, turnover, and functions of chitin in insects. Ann. Rev. Entomol. 61:177-196. 